\title{
Improving The Compliance With Accounting Standards Without Public Accountability (SAK ETAP) By Developing Organizational Culture: A Case Of Indonesian SMEs
}

Heri Yanto, Universitas Negeri Semarang, Indonesia

Arief Yulianto, Universitas Negeri Semarang, Indonesia

Lesta Karolina Boru Sebayang, Universitas Negeri Semarang, Indonesia

Fian Mulyaga, Universitas Negeri Semarang, Indonesia

\begin{abstract}
In Indonesia's economy SMEs have significant contribution to GDP and labor employment. On the other hand, SMEs still have substantial problems. One of them is related to capital insufficiency due to limited access of SMEs to financial institutions. This limitation may be caused, among other things, by the fact that SMEs'financial statements have not complied with Accounting Standards without Public Accountability (SAK ETAP). The study aims at identifying antecedents of SAK ETAP implementation as well as formulating strategies to improve its implementation in SMES. Five important antecedents of SAK ETAP implementation are organizational culture, education, exposure, age, and scale. Therefore, developing organizational culture by increasing SMEs' exposure on socialization and training is a promising strategy. There is also a need for more intensive cooperation of various parties such as government, Institute of Indonesian Chartered Accountants (IAI), universities, SME association, and NGOs to improve both SMEs' compliance with SAK ETAP and organizational culture. In addition, mobilization of academic staffs and accounting students to facilitate the implementation of SAK ETAP is worth-trying.
\end{abstract}

Keywords: SAK ETAP Implementation; Organizational Culture; Indonesian SMEs

\section{INTRODUCTION}

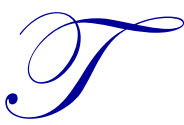

he contribution of SMEs to Indonesia's economy is considered significant indicated by the fact that these enterprises contributed 53\% of Indonesia's GDP in 2006 (Tambunan, 2011) and increasing up to $57 \%$ in 2015 (Sarwono, 2015). Likewise, SMEs also employ 97\% of Indonesian labor force (Sarwono, 2015; Tambunan, 2011). Nevertheless, until recently SMEs still have various fundamental problems (Sudaryanto, Ragimun, \& Wijayanti, 2013; Suliyanto, Suroso, \& Jati, 2013; Tambunan, 2011). One of the problems is limited access to financial institutions (Sudaryanto et al., 2013). This is most likely due to their limited financial information or their less standard-compliant financial statements (Rudiantoro \& Siregar, 2012).

Accounting Standards without Public Accountability (SAK ETAP) - accounting standards for SMEs - have been legalized by the Board of Financial Accounting Standards in 2009 and have been effective since the beginning of 2011 (Zahro \& Wahyundaru, 2015). Since then, the efforts of socializing these financial standards have been made by the ministry of cooperative and SME. Nevertheless, the adoption of these standards to prepare SME's financial statements has yet reached satisfactory result. So far, many SMEs have not fully implemented SAK ETAP (Kurniawati, Nugroho, \& Arifin, 2012; Saragih \& Surikayanti, 2015; Zahro \& Wahyundaru, 2015). Hence, many of these companies fail to provide financial statements or financial information complied with the standards required by financial institutions to make decision on loan granting. In addition to being a requirement to apply for loan to financial institutions, SME's 
financial statements based on SAK ETAP could also provide information for making decisions (Carraher \& Van Auken, 2013; Putri, Purwati, \& Suparlinah, 2015).

Research on the implementation of SAK ETAP within Indonesia's business context has been conducted by several academicians to study SME's behavior in implementing these accounting standards. Most of these studies are still preliminary to discover the status of SAK ETAP implementation in SMEs. These preliminary studies have been performed by, among others, Kurniawati et al. (2012), Saragih and Surikayanti (2015), and Lutfiaazahra (2015). The following research on SAK ETAP aims at identifying the factors influencing the implementation of SAK ETAP among SMEs in Indonesia. This type of studies treat determinant variables in parallel in influencing the implementation of SAK ETAP without considering theoretically and empirically supported relationships among those determinant variables. Such kind of research has been conducted by Zahro and Wahyundaru (2015), Susanto and Yuliani (2015), and Putri et al. (2015). Research on Indonesian SME's behavior in accepting SAK ETAP with broader model has been performed by Yanto, Handayani, Solikhah, and Mula (2016). Nevertheless, this research focuses only on the intention to use SAK ETAP (Yanto et al., 2016), it has not discussed about the behavior of SMEs in using SAK ETAP.

This study aims at identifying the antecedent variables of SAK ETAP implementation in SMEs by carefully considering the pattern of sequential relationships among antecedent variables which is supported by theories. In Indonesian business context, not many studies of this kind have been conducted. The study identifies the extent of SAK ETAP implementation as well as formulates strategies for accelerating the implementation of SAK ETAP in SMEs. Therefore, the study would benefit some parties such as government, IAI, SME association, and universities.

\section{LITERATURE REVIEW}

Until recently, the number of SMEs in Indonesia has reached 56.54 million units and employs Indonesian labor force up to $99.99 \%$ (Sarwono, 2015, p. 16). However, many SMEs are still having difficulties to implement accounting with the generally-accepted standard. In other words, SAK ETAP implementation by SMEs is still relatively low and simple (Kurniawati et al., 2012; Saragih \& Surikayanti, 2015; Zahro \& Wahyundaru, 2015). SAK ETAP implementation could serve at least provide managerial information for making decisions (Carraher \& Van Auken, 2013; Putri et al., 2015) and fulfill the requirement to access loan to financial institutions (Narsa, Widodo, \& Kurnianto, 2012; Sudaryanto et al., 2013; Susanto \& Yuliani, 2015).

SAK ETAP implementation is the extent of accounting implementation in SMEs using these standards. SME's financial statements based on SAK ETAP are Balance Sheet, Income Statement, Statement of Changes in Equity, Statement of Cash Flow, and Notes to the Financial Statement (IAI, 2009). Therefore, in order to prepare such financial statements, SMEs should have a complete accounting cycle consisting of Journal, Posting, Balance Sheet, Adjustment, Work Sheet, and Financial Reports (Priyatno, 2009, pp. 16-20). Even though these standards could be applied in a simple way, many SMEs still find it difficult to implement.

\subsection{Organizational Culture and SAK ETAP Implementation}

Accounting standards for SMEs have been issued in 2009 (IAI, 2009) and should have been implemented by SMEs in the beginning of 2011 (Zahro \& Wahyundaru, 2015). In reality, however, SAK ETAP implementations in SMEs have not been satisfactory. Such condition is most likely caused by the limited source of financing (Cant \& Wiid, 2016) as well as limited human resources (Cant \& Wiid, 2016; Sudaryanto et al., 2013). For most SMEs, SAK ETAP is considered as technology (Yanto et al., 2016) that its implementation is influenced by the perception and behavior of those inside the SMEs.

Attitude and behavior in companies are critical in implementing an effective development policy (Petts, Herd, Gerrard, \& Home, 1999). For example, Fatrisia and Raharja (2015) find that entrepreneurship behavior influence SMEs' performance. Likewise, Abdul Rashid, Sambasivan, and Abdul Rahman (2004) find that organizational culture is closely related with attitude toward organizational change. It is highly possible since organizational culture would influence employees' commitment (Inanlou \& Ahn, 2016). For example, Koutroumanis, Watson, and Dastoor (2011) find that organizational culture influences service quality and, at the same time, influences customers' intention to return. 
SAK ETAP could be treated as an innovation in SME accounting that its implementation could be influenced by organizational culture. The study of Khazanchi, Lewis, and Boyer (2007) and Yeşil and Kaya (2012) find that innovation is influenced by organizational culture. It is most likely that SAK ETAP adoption by SMEs is also influenced by organizational culture as studied by Senarathna, Warren, Yeoh, and Salzman (2014) that e-commerce adoption by Sri Lanka's SMEs is influenced by adhocracy-type organizational culture. SAK ETAP as new accounting standards could be deemed as an innovation whose implementation is also influenced by organizational culture. Organizational culture is values, principles, traditions, and ways shared by members of an organization which influence them in the way they act (Robbins \& Coulter, 2012). Despite their simple, traditional, conventional form (Widyastutik, Mulyati, \& Putri, 2010), organizational culture could be applicable in Indonesian SMEs. Furthermore, Robbins and Coulter (2012) suggest seven dimensions of organizational culture i.e. innovation and risk taking, attention to detail, outcome orientation, people orientation, team orientation, aggressiveness, and stability. Robbins and Coulter (2012) also state that organizational culture based on these dimensions has a range from high to low. Based on the above literature review, this research formulates the following hypothesis:

H1: Organizational culture has positive influence on SAK ETAP implementation by SME.

\subsection{The Roles of Manager's Education}

Education and training would equip managers with a basic framework for improving business quality (Abdullah, Uli, \& Ismail, 2009) within the constantly changing and competitive business environment (Daou, Karuranga, \& Su, 2013). In addition, education also influences one's perception about risk, technology, and credibility (Al-Gahtani, 2011). In relation to that, education is likely to influence managers' understanding over accounting (Supriyati \& Wulanditya, 2012). Therefore, the role of management in building organizational culture is pivotal starting from building trustworthiness, empowerment, delegation, consistency, and mentorship (Kane-Urrabazo, 2006). Education also plays an important role in building life skills of graduates (Kiswoyowati, 2011). Life skills are not just limited to how the graduates work, rather they include the skills to find and process information. Nevertheless, Indonesian SMEs still have to face human resources issue (Sudaryanto et al., 2013), leading to the constant need for socialization and training (Rudiantoro \& Siregar, 2012). Furthermore, training and development are keys to SME's success and survival (Rabie, Cant, \& Wiid, 2016). Therefore, the level of education has the possibility to influence manager to participate in exposure activities in the form of SAK ETAP socialization and training. Based on those findings, this study posits the following hypotheses:

H2: Manager's education influences SAK ETAP implementation.

H3: Education influences managers' ability in building organizational culture of SMEs

H4: Education influences managers' participation in SAK ETAP exposure activities.

\subsection{Manager's Exposure on SAK ETAP}

Various parties have performed socialization and training of these standards to SME managers or owners. There are at least four parties performing these activities such as Office of Cooperative and SME, Institute of Indonesia Chartered Accountants (IAI), Universities, and Non-Governmental Organizations (Rudiantoro \& Siregar, 2012). Exposure - socialization and training - is pivotal for building business quality. Training and development are keys to SME's success and survival has been proven (Rabie et al., 2016). Previous research also finds that training equips managers with knowledge and skills for developing better business (Abdullah et al. 2009). In addition, Zakaria, Zainal, and Nasurdin (2012) conclude that human resources management plays an important role in developing SMEs. Considering the importance of SMEs in the economy, the development of SMEs to improve intellectual capital quality becomes considerably strategic (Daou et al., 2013).

Managers participating in socialization and training more frequently tend to be more acquaintance with SAK ETAP. This could lead managers to implement the standards in their companies. Moreover, upon socialization and training, the managers would likely to have more information about best practices from the outside to build organizational culture in their own companies. Given that the number of SMEs is over 56 million units (Sarwono, 2015), a cluster- 
based SME development is still promising (Widyastutik et al., 2010). Thereby, this research formulates the following two hypotheses:

H5: Managers' exposure influences SAK ETAP implementation in SMEs.

H6: Exposure influences manager's ability to build organizational culture.

\subsection{SME Scale}

The factors influencing business performance in small and big SMEs are significantly different (Park \& Yoo, 2016). From the perspective of their organizational culture, smaller companies have more homogeneous organizational culture while the bigger ones tend to have those with sub-organizational culture (Doina, Mirela, \& Constantin, 2008). Additionally, SMEs are also managed in a simpler way compared to bigger companies (Widyastutik et al., 2010). Using the seven dimensions of organizational culture suggested by Robbins and Coulter (2012), it is likely that companies with bigger scale would have a more stable organizational culture. Other than a more stable organizational culture, bigger companies possibly have higher need for implementing generally-accepted accounting. Previous research finds that SME size, as measured by its number of employees, has significant influence on its readiness to implement IFRS (Kiliç, Uyar, \& Ataman, 2016). However, Dang-Duc (2011) provides different results in Vietnam that SME size has no correlation with compliance with accounting standards. There is a possibility that the context of SME business and policy in Indonesia and Vietnam is relatively different, hence this research formulates the following two hypotheses:

H7: Company scale influences organizational culture in SMEs.

H8: Company scale significantly influences the implementation of SAK ETAP in SMEs.

\subsection{Company's Age}

Company age or the length a company has been in business is the reflection of experience in running business as well in solving business problems (Zen \& Herman, 2012). Previous studies find that age influences stability, productivity, profit, scale, and leverage (Coad, Segarra, \& Teruel, 2013). This result also implies that older company tends to have better business management and organizational culture. The impact of organizational culture on company performance is significant (Abdullah, Shamsuddin, Wahab \& Hamid, 2013; Koutroumanis et al., 2011; Owoyemi \& Ekwoaba, 2014). To discover the correlation between company age and accounting standard implementation Dang-Duc (2011) finds that SMEs have different characteristics from that of bigger companies. However, Kiliç et al. (2016) suggests that age does not influence SME readiness to apply IFRS. Meanwhile, Coad et al. (2013) state that SME's age does influence company scale. Based on the above literature review, this research formulates the following hypotheses:

H9: Company age does not influence SAK ETAP implementation in SMEs

H10: Company age influences SME's Organizational Culture

H11: Company age influences SME scale (size)

\section{METHODOLOGY}

\subsection{Research variables}

This study employs six variables i.e. SAK ETAP, Organizational Culture, Exposure, Scale, Age, and Education. SAK ETAP variable measures the extent of SMEs in implementing Accounting Standards without Public Accountability. Using SAK ETAP indicators as suggested by IAI (2009) and Priyatno (2009), this research tries to design seven-point Likert type questionnaire. Organizational Culture variable measures how principles, values, and traditions are followed and practiced by SMEs in their action (Robbins \& Coulter, 2012). From this operational definition, Robbins and Coulter (2012, pp. 51-52) then suggest seven dimensions of organizational culture on which the Likert-type 
questionnaire at five point scale is designed. Exposure variable measures to what extent SME managers obtain information on SAK ETAP through mass media, seminar, and training organized by many parties (Rudiantoro \& Siregar, 2012). This indicator is used to design likert questionnaire at five point scale. To measure an SME scale or size, this research uses the number of employees as proxy as conducted by Kiliç et al. (2016) as well as Park and Yoo (2016). Age variable is measured by the number of year an SME has been in business and Education variable is proxied by the number of years for managers to attain the highest level of formal education.

\subsection{Sampling Method}

This study uses convenient sampling by distributing questionnaires to managers attending activities at the Office of Cooperative and SME. These SME managers come from all regencies and municipalities in Central Java. Out of 205 collected data, only 192 could be analyzed further.

\subsection{Questionnaire Development}

Based on the operational definitions and indicators, this research develops a questionnaire and trials it on 30 SME managers from Semarang Municipality area. Corrected-item-total correlation and Cronbah's alpha analyses are used to test validity and reliability (de Vaus, 2002). The threshold values of corrected item-total correlation and Cronbah's alpha are 0.3 and 0.7 respectively (de Vaus, 2002). The results of trial indicate that all question items meet the validity and reliability requirements. After collecting data, the study conducts validity and reliability tests using sample data of 192 to provide more accurate estimation.

The validity and reliability tests on items of SAK ETAP by using corrected item-total correlation give good validity coefficients. The lowest correlation coefficient is 0.763 with Cronbach's alpha coefficient of 0.972 . The organizational culture variable which uses seven dimensions (Robbins \& Coulter, 2012) has the lowest correlation coefficient of 0.373 with Cronbach's alpha at 0.924 . The exposure variable measured by six items has satisfactory validity test results. The minimum correlation score is 0.571 with Cronbach's alpha coefficient of 0.829 .

\subsection{Multivariate Normality}

Multivariate normality analysis shows a point of 14.85 , meaning that the coefficient is not normal compared to its maximum threshold of 2.58 (Ghozali, 2007). The same goes to kurtosis multivariate coefficient which indicates a point of 21.00 at a maximum tolerable value of 10 (Widhiarso, 2012). Therefore, this research performs a bootsrapping using Bollen-Stine technique as suggested by Ghozali (2007) and Widhiarso (2012). Using bootstrap sample of 2,000, Bollen-Stine bootstrap analysis provides coefficient of $0.082(p>0.05)$, meaning that the data distribution meets requirement for further analysis.

\subsection{Data Analysis}

This research uses descriptive, correlation, and path analyses. The objective of correlation analysis is to provide comparison with the results of path analysis, since correlation analysis is not influenced by correlations from other variables. Path analysis aims at identifying causal relationship of a group of variables. This analysis is considered more flexible, as it can analyze causal relationships from two or more regression analyses simultaneously (Edwards \& Lambert, 2007). Nevertheless, standardized path coefficient should be above 0.2 for it to be deemed significant (Chin, 1998). Based on the literature review, the research model has two exogeneous variables (Education and Age) and four endogeneous variables (Scale, Exposure, Organizational Culture, and SAK ETAP).

The model constructed by the study has eleven hypotheses to be tested simultaneously using path analysis. The model is also tested using goodness of fit test (Byrne, 2010; Cheung \& Rensvold, 2002; Ghozali, 2007) to find out that the model has been supported by empirical data (Yanto et al., 2016). To test goodness of fit, this study uses six indices i.e. Chi Squared, Goodness of Fit Index (GFI), Adjusted Goodness of Fit Index (AGFI), Root Mean Square of Approximation (RMSEA), Normed Fit Index (NFI), and Comparative Fit Index (CFI), and CMIN/d.f. as suggested by Cheung and Rensvold (2002), Ghozali (2007), and Hoe (2008). The thresholds for these indices are as follows: Chi-square should have insignificant $p$ value or $(p>0.05)$; fit value of GFI, AGFI, NFI, CFI should be above 0.90; 
RMSEA value should be below 0.08; and the value of CMIN/d.f. should be below 3.0 (Cheung \& Rensvold, 2002; Ghozali, 2007; Hoe, 2008).

\section{RESULTS DISCUSSION}

\subsection{Descriptive Analysis}

Descriptive analysis shows that the minimum score of SAK ETAP variable is 16 , meaning that SMEs do not use SAK ETAP, and the maximum score is 112 meaning that SMEs have fully implemented these standards. The mean of SAK ETAP implementation is still in the range of 52.07 of the maximum score 112, that is the number of items (16) multiplied by maximum score of each item (7). In other words, on average the SAK ETAP implementation is still relatively low. The number of items on organizational culture is 20 with 5 points as the maximum score of each item. Therefore, the sum of maximum score is 100 . The average score of organizational culture is 79.28. Likewise, the minimum score of exposure is 6, meaning that SME manager has the lowest exposure on SAK ETAP while the highest score is 30. On average the SME exposure on SAK ETAP is 12. The following table provides more detailed information about the results of descriptive analysis.

Table 1. Descriptive Analysis

\begin{tabular}{l|c|c|c|c}
\hline Variable & Min. & Max. & Mean & Std. Deviation \\
\hline SAK_ETAP & 16 & 112 & 52.07 & 26.83 \\
\hline EXPOSURE & 6 & 30 & 12.00 & 4.63 \\
\hline EDUCATION & 1 & 6 & 3.39 & 1.18 \\
\hline SCALE & 1 & 45 & 5.42 & 6.31 \\
\hline AGE & 1 & 37 & 5.71 & 5.70 \\
\hline ORG_CULTURE & 45 & 100 & 79.28 & 10.84 \\
\hline
\end{tabular}

\subsection{Correlation}

Correlation analysis indicates that the implementation of SAK ETAP in SMEs is related to organizational culture $(0.387, p<0.01)$, company scale $(0.369, p<0.01)$, exposure $(0.244, p<0.01)$, and manager or owner education $(0.192$, $p<0.01)$. Company age does not correlate with SAK ETAP implementation $(0.053, p>0.05)$. As an intervening variable, organizational culture is related to company scale $(0.232, p<0.01)$, and exposure $(0.293, p<0.01)$. The company age and education variables do not correlate with organizational culture with the coefficients of $(0.017$, $p>0.05)$ and $(0.092, p>0.05)$ respectively. This research also finds that company age correlates with company scale $(0.335, p<0.01)$. In other words, older SME tends to have bigger business scale. The table below presents the correlation matrix which describes the correlation among variables in this study.

Table 2. Correlation Matrix

\begin{tabular}{|c|c|c|c|c|c|}
\hline & ORG. CULTURE & AGE & SCALE & SOCIALIZATION & EDUCATION \\
\hline AGE & 0.017 & 1 & & & \\
\hline SCALE & $0.232^{* *}$ & $0.335^{* *}$ & 1 & & \\
\hline EXPOSURE & $0.293^{* *}$ & $-0.154^{*}$ & 0.048 & 1 & \\
\hline EDUCATION & 0.092 & -0.127 & 0.033 & 0.125 & 1 \\
\hline SAK_ETAP & $0.387^{* *}$ & 0.053 & $0.369^{* *}$ & $0.244^{* *}$ & $0.192^{* *}$ \\
\hline
\end{tabular}

**Correlation is significant at the 0.01 level (2-tailed)

*Correlation is significant at the 0.05 level (2-tailed)

\subsection{Path Analysis}

Path analysis shows that SAK ETAP implementation is influenced by organizational culture with beta coefficient of 0.268 ( $p<0.001)$, company scale $(0.304, p<0.001)$, manager's level of education $(0.141, p<0.05)$, and exposure $(0.133$, $p<0.05)$. The education variable does not directly influence SAK ETAP implementation with beta of $0.141(p>0.05)$. As an intervening variable, organizational culture is influenced by exposure of SAK ETAP with beta coefficient of 
$0.283(p<0.001)$. In addition, organizational culture is also influenced by company scale with beta coefficient of 0.219 $(p<0.001)$. Manager's education does not have significant influence on SAK ETAP exposure activities with beta coefficient of $0.125(p>0.05)$. This research finds that company age positively and significantly influence company scale with beta of $0.335(p<0.001)$. For more detail, presented below are all beta coefficients of path analysis.

Table 3. Summary of Path Analysis

\begin{tabular}{|c|c|c|c|c|}
\hline & & & Std. Regression Weight & $p$ \\
\hline EXPOSURE & $<---$ & EDUCATION & 0.125 & 0.081 \\
\hline SCALE & $<---$ & AGE & 0.335 & ${ }^{* * *}$ \\
\hline ORG_CULTURE & $<---$ & EDUCATION & 0.049 & 0.473 \\
\hline ORG_CULTURE & $<---$ & AGE & -0.007 & 0.922 \\
\hline ORG_CULTURE & $<---$ & EXPOSURE & 0.276 & $* * *$ \\
\hline ORG_CULTURE & $<---$ & SCALE & 0.220 & 0.002 \\
\hline SAK_ETAP & $<---$ & ORG_CULTURE & 0.267 & \\
\hline SAK_ETAP & $<---$ & EXPŌSURE & 0.133 & 0.046 \\
\hline SAK_ETAP & $<---$ & SCALE & 0.304 & ${ }^{* * *}$ \\
\hline SAK ETAP & $<---$ & AGE & -0.014 & 0.831 \\
\hline SAK_ETAP & $<---$ & EDUCATION & 0.141 & 0.026 \\
\hline
\end{tabular}

*** Significant at the 0.001 level

This study proposes eleven hypotheses, eight of which are accepted (H1, H2, H5, H6, H7,H8, H9, H11) and the remaining three hypotheses are rejected $(\mathrm{H} 3, \mathrm{H} 4$, and $\mathrm{H} 10)$. There is no significant difference between the results of correlation and path analysis. The following figure presents antecedents of SAK ETAP implementation using organizational culture as an intervening variable.

Figure 1. Antecedents of SAK ETAP Implementation

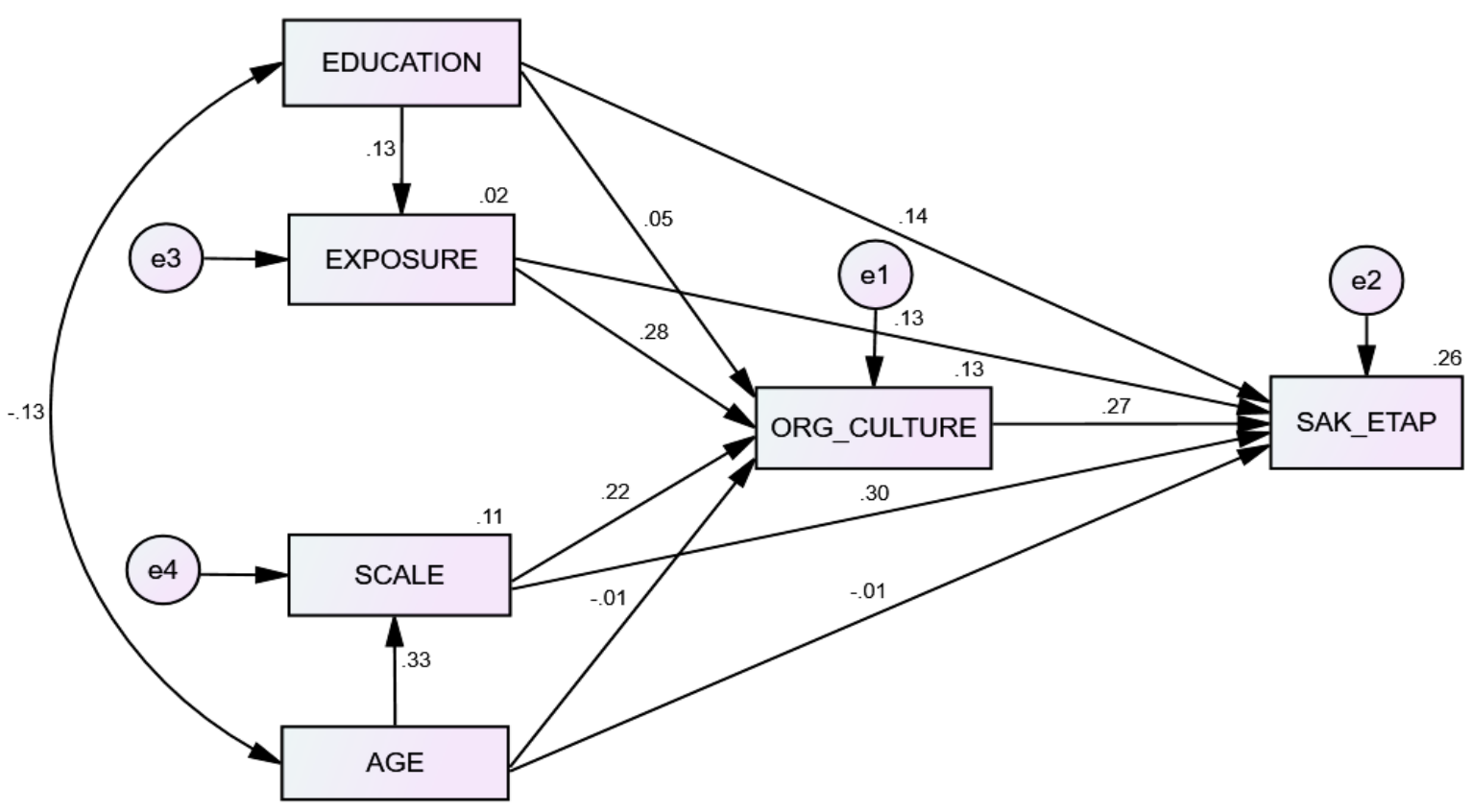




\subsection{Goodness of Fit Test}

Multivariate normality problem has been solved using Bollen Stine bootstrapping technique as explained in the previous part. The results of goodness of fit test provide Chi Square of 6.975 ( $p>0.05)$, meaning that the built model is supported by empirical data. RMSEA of 0.083 is deemed fit, because it is close to the predetermined threshold, i.e. below 0.08. Other indices such as CMIN/d.f., GFI, AGFI, NFI, and CFI show fit coefficients. Therefore, the model has met most of Goodness of Fit Test.

Table 4. Goodness of Fit Test

\begin{tabular}{l|c|c|c}
\hline \multicolumn{1}{c|}{ Index } & Cut-off Value & Empirical Test & \multicolumn{2}{c}{ Remark } \\
\hline Chi Squared & $\alpha \geq 5 \%$ & $6.975,(p=0.073)$ & Fit \\
\hline RMSEA & $\leq 0.08$ & 0.083 & Fit \\
\hline CMIN/d.f. & $\leq 3.0$ & 2.325 & Fit \\
\hline GFI & $\geq 0.9$ & 0.988 & Fit \\
\hline AGFI & $\geq 0.9$ & 0.918 & Fit \\
\hline NFI & $\leq 0.9$ & 0.944 & Fit \\
\hline CFI & $\geq 0.9$ & 0.964 & Fit \\
\hline
\end{tabular}

\subsection{Discussion}

The descriptive analysis indicates that the SAK ETAP implementation among SMEs is still relatively low. This result is in line with the results of studies conducted by Kurniawati et al. (2012), Saragih and Surikayanti (2015), as well as Zahro and Wahyundaru (2015). Considering the importance of SMEs in Indonesian economy (Sarwono, 2015; Tambunan, 2011), the implementation of SAK ETAP should immediately be improved by involving various parties. Even though socialization and training on SAK ETAP have been performed (Rudiantoro \& Siregar, 2012) there has been no satisfactory result. It is likely that SMEs in general still have such obstacles as human resources (Cant \& Wiid, 2016; Sudaryanto et al., 2013) and source of financing (Cant \& Wiid, 2016). Therefore, new strategies are needed to improve the quantity and quality of SAK ETAP implementation. One of the strategies offered by this study is building SME's organizational culture.

Correlation analysis indicates that there is a significant relationship between SME's organizational culture and SAK ETAP implementation. The path analysis also shows the same result where the influence of SME's organizational culture on SAK ETAP implementation is significant. Thereby, the quality of SAK ETAP implementation is significantly influenced by organizational culture. In other words, the behavior in SMEs influences their effective business development (Petts et al., 1999) and influences SMEs' performance (Fatrisia \& Raharja, 2015), because organizational culture influences employee's commitment (Inanlou \& Ahn, 2016) and improves the quality of services given by employees (Koutroumanis et al., 2011). These findings also confirm the previous study that new technology implementation is influenced by both organizational value (Khazanchi et al., 2007) and organizational culture (Yeşil \& Kaya, 2012). For example, Senarathna et al. (2014) finds that e-commerce adoption is also influenced by organizational culture. In addition, organizational culture using seven dimensions suggested by Robbins and Coulter (2012) could be good predictors of SAK ETAP implementation, despite SME's simple forms and businesses (Widyastutik et al., 2010). Hence, the improvement of SME's organizational culture could be one strategy to improve SAK ETAP implementation. The next problem is how to develop SME's organizational culture.

SME managers' exposure to SAK ETAP seems to be the most interesting strategy to build organizational culture. The research result indicates that the influence of SAK ETAP exposure on SME's organizational culture is significant. The term exposure here means the acquisition of information on SAK ETAP from both mass media and training. The socialization performed by various parties such as universities, NGOs, government, and IAI (Rudiantoro \& Siregar, 2012) ought to be done more massively. Building organization culture by increasing managers' exposure seems to be more important, since managers' exposure on SAK ETAP is still relatively low. This is confirmed even further by Rabie et al. (2016) that education and development are keys to SME business success and survival. So far, the influence of exposure on organizational culture is greater than that of exposure on SAK ETAP implementation. It means that organizational culture development would not just improve SAK ETAP implementation; rather it will also improve 
business as suggested by Petts et al. (1999). Effective organizational culture and business would at least increase SMEs' financial performance.

A manager's formal education positively influences SAK ETAP implementation $(0.141, p<0.05)$. Nonetheless, this influence is considered small in magnitude, since the coefficient of standardized regression weight is still below 0.2 (Chin, 1998). The weak influence of education on SAK ETAP implementation is probably caused by the fact that SME manager's formal education does not equip them with sufficient accounting and business knowledge. The same goes to the influence of manager's education on both their ability in developing organizational culture and exposure activities, which are not significant either. This does not confirm what Supriyati and Wulanditya (2012) hypothesize that manager's education will have some influence on their understanding about accounting. In other words, SME managers take a passive role by waiting others to lend them a hand. The affirmation and interference from other parties facilitated by the government become even more important to develop SME businesses, because SMEs have limited resources (Cant \& Wiid, 2016; Sudaryanto et al., 2013), yet SMEs have already needed to develop their intellectual capital (Daou et al., 2013).

The results of this research indicate that company age neither influences SAK ETAP implementation nor organizational culture development. These findings are not in line with the results of previous studies that bigger and older company would be more capable of solving their business problems (Zen \& Herman, 2012) and better performance (Coad et al., 2013). It is likely that SMEs have limited human resources as reported by Sudaryanto et al. (2013) as well as Cant and Wiid (2016). The impact is that the businesses run by SMEs are still simple and traditional (Widyastutik et al., 2010). Thus, older SMEs do not necessarily mean that they are more capable of developing organizational culture or implementing SAK ETAP. Company age only influences the business scale proxied by the number of employees. It also means that SME business scale develops as the company gets older, yet a business age does not guarantee that their organizational culture and SAK ETAP implementation will develop.

The business scale has positive influence on organizational culture and SAK ETAP implementation. A bigger company tends to have better organizational culture and more capacity to implement SAK ETAP. Therefore, bigger and smaller SMEs need to be treated differently (Park \& Yoo, 2016). Doina et al. (2008) also confirm that the bigger the company the more complex their organizational culture will be. In related to the influence of company scale on accounting implementation; Kiliç et al. (2016) find that there is a significant correlation between company size and their readiness for IFRS implementation. It is likely that bigger SMEs will have bigger needs for the implementation of accounting that complies with the standards for the purpose of providing information (Carraher \& Van Auken, 2013; Putri et al., 2015) and of fulfilling the requirements to apply for some loans to financial institutions (Narsa et al., 2012; Susanto \& Yuliani, 2015).

SME manager's education, business scale, and age are those variables which cannot change in the short term to improve SAK ETAP implementation. The exposure and organizational culture variables have higher possibility of being controlled to improve SAK ETAP implementation in SMEs. The development of SME's organizational culture through exposure, delivery of information and training is a promising strategy as suggested by Rabie et al. (2016). The problem is that the number of SMEs is $97 \%$ or 56.54 million of all businesses in Indonesia (Sarwono, 2015; Tambunan, 2011). Socialization and assistance by the government, IAI, Universities, and NGOs as suggested by Rudiantoro and Siregar (2012) are still the most interesting way, yet a modified strategy is needed. The strategy of developing and empowering clusters as suggested by Widyastutik et al. (2010) is a simple and inexpensive one, because socialization and training to SMEs could be performed in groups. In addition, clusters could serve as a center to share best practices for SMEs, enabling acceleration of SME development. Nevertheless, the number of human resources from government, NGOs, and IAI is not sufficient to handle large number of SMEs.

Academic staff and accounting student deployment (AASDP) - assigning academic staffs and accounting students to assist SMEs - could be performed to solve the constraint of human resources. Considering that the number of universities in Indonesia with accounting department has reached a number of 1,077 (BAN-PT, 2017), making students and lecturers are capable of facilitating more SMEs. Accounting students taking public services course or internship could be directed to take thematic scheme particularly related to the socialization, training, and assistance to SMEs. Thereby, SMEs could develop their organizational culture to effectively accelerate their business improvement (Petts et al., 1999) as well as to improve SAK ETAP implementation. 


\section{CONCLUSION}

SAK ETAP as accounting standards for SMEs has not been implemented optimally. The mean implementation of these standards still needs improving. SAK ETAP implementation in SMEs is influenced by organizational culture, exposure, business scale, and owner's education. Company age does not influence the implementation of SAK ETAP in SMEs. As an intervening variable, organizational culture is influenced by manager's exposure to SAK ETAP and SME scale. The age of SME and manager's education do not influence the improvement of SME's organizational culture. SME having longer period in doing business tends to have bigger scale. The formal education of SME's manager does not guarantee manager's level of exposure to SAK ETAP.

The most interesting strategy to improve SAK ETAP implementation is to build SME's organizational culture by increasing SME manager's exposure to SAK ETAP. Considering the importance of organizational culture to develop SMEs and SAK ETAP implementation, exposure is not limited to just accounting standard implementation, rather it should also include such material as organizational culture. Therefore, universities, IAI, government, SME association ought to work hand in hand to empower SMEs based on clusters. Academic staff and accounting student deployment program (AASDP) to facilitate SMEs in developing organizational culture and SAK ETAP implementation is also an interesting strategy.

The main limitation of the study is on the sampling technique. The study employs convenient sampling that could cause unrepresentative samples. Even though, the office of cooperative and SME invited SME managers-respondent of the study - from all regencies in Central Java, further research should use more systematic sampling technique. The next research needs to perform a piloting project of AASDP based on cluster and evaluate the effectiveness of the program.

\section{AUTHOR BIOGRAPHIES}

Heri Yanto, Associate Professor (Lektor Kepala) at Accounting Department, Fakultas Ekonomi, Universitas Negeri Semarang. He has conducted some research in the areas of Accounting Behavior, Environmental Accounting, and Accounting Education. He has experience working with International NGOs to develop education in developing countries.

Arief Yulianto, Assistant Professor (Lektor) at Management Department, Fakultas Ekonomi, Universitas Negeri Semarang. He is interested in conducting research on Financial Management both for SME and corporate companies.

Lesta Karolina Boru Sebayang, Assistant Professor (Lektor) at Department of Economics Development, Fakultas Ekonomi, Universitas Negeri Semarang. She is interested in conducting research on public finance, econometrics, and economic development especially the empowerment of SMEs.

Fian Mulyaga, was a student and research assistant at Accounting Department, Faculty of Economics, Universitas Negeri Semarang. To complete her final project, she worked with her supervisor to conduct research on Accounting for SMEs in Indonesian business context. Currently she is working full time in the biggest Cooperative banking in Indonesia.

\section{REFERENCES}

Abdul Rashid, Z., Sambasivan, M., \& Abdul Rahman, A. (2004). The influence of organizational culture on attitudes toward organizational change. Leadership \& Organization Development Journal, 25(2), 161-179.

Abdullah, M. M. B., Uli, J., \& Ismail, A. (2009). Training and education program as a major determinant quality improvement in Malaysian electrical and electronic Industry. International Journal of Business and Management Science, 1(2), 205209.

Abdullah, N. H., Shamsuddin, A., Wahab, E., \& Hamid, N. A. A. (2013). The Relationship between Organizational Culture and Product Innovativeness. Paper presented at the International Conference on Innovation, Management and Technology Research, Malaysia.

Al-Gahtani, S. S. (2011). Modeling the electronic transactions acceptance using an extended technology acceptance model. Applied Computing and Informatics, 9(1), 47-77. 
BAN-PT. (2017). Direktori SK Hasil Akreditasi Program Studi Retrieved January 20, 2017, from http://banpt.kemdiknas.go.id/direktori.php

Byrne, B. M. (2010). Structural Equation Modeling with AMOS: Basic Concepts, Aplications, and Programming (2nd ed.). New York: Taylor \& Francis Group.

Cant, M. C., \& Wiid, J. A. (2016). Internet-Based ICT Usage By South African SMEs: The Barriers Faced By SMEs. The Journal of Applied Business Research, 32(6), 1877-1887.

Carraher, S., \& Van Auken, H. (2013). The use of financial statements for decision making by small firms. Journal of Small Business \& Entrepreneurship, 26(3), 323-336.

Cheung, G. W., \& Rensvold, R. B. (2002). Evaluating Goodness-of-Fit Indexes for Testing Measurement Invariance. Structural Equation Modeling, 9(2), 233-255.

Chin, W. W. (1998). Commentary: Issues and opinion on structural equation modeling. MIS Quarterly, 22(1), vii-xvi.

Coad, A., Segarra, A., \& Teruel, M. (2013). Like milk or wine: Does firm performance improve with age? Structural Change and Economic Dynamics, 24(C), 173-189.

Dang-Duc, S. (2011). Compliance with accounting standards by SMEs in transitional economies: evidence from Vietnam. Journal of Applied Accounting Research, 12(2), 96-107.

Daou, A., Karuranga, E., \& Su, Z. (2013). Intellectual Capital In Mexican SMEs From The Perspective Of The Resource-Based And Dynamic Capabilities Views. The Journal of Applied Business Research, 29(6), 1673-1688.

de Vaus, D. (2002). Surveys in social research. Crows Nest NSW: Allen \& Unwin.

Doina, R., Mirela, S., \& Constantin, R. (2008). The Organizational Culture and the Factors of Its Formation. Annals of the University of Oradea, Economic Science Series, 17(4), 559-562.

Edwards, J. R., \& Lambert, L. S. (2007). Methods for Integrating Moderation and Mediation: A General Analytical Framework Using Moderated Path Analysis. Psychological Methods, 12(1), 1-22.

Fatrisia, A., \& Raharja, E. (2015). The influence of company characteristics, entrepreneurship behavior and bank relationship toward small and medium enterprises (SMEs) performance. Jurnal Dinamika Akuntansi, 6(1), 1-20.

Ghozali, I. (2007). Structural equation modelling: Konsep dan aplikasi dengan AMOS. Semarang.: Badan Penerbit Universitas Diponegoro.

Hoe, S. L. (2008). Issue and procedures in adopting structural equation modeling technique. Journal of Applied Quantitative Method, 3(1), 76-83.

IAI. (2009). Standar Akuntansi Keuangan Entitas Tanpa Akuntabilitas Publik. Jakarta: Dewan Standar Akuntansi Keuangan.

Inanlou, Z., \& Ahn, J.-Y. (2016). The Effect Of Organizational Culture On Employee Commitment: A Mediating Role Of Human Resource Development In Korean Firms. The Journal of Applied Business Research, 33(1), 87-94.

Kane-Urrabazo, C. (2006). Management's role in shaping organizational culture. Journal of Nursing Management, 14, 188-194.

Khazanchi, S., Lewis, M. W., \& Boyer, K. K. (2007). Innovation-supportive culture: The impact of organizational values on process innovation. Journal of Operations Management, 25(4), 871-884.

Kiliç, M., Uyar, A., \& Ataman, B. (2016). Preparedness of the entities for the IFRS for SMEs: an emerging country case. Journal of Accounting in Emerging Economies, 6(2), 156-178.

Kiswoyowati, A. (2011). Pengaruh motivasi belajar dan kegiatan belajar siswa terhadap kecakapan hidup siswa. Portal Jurnal Universitas Pendidikan Indonesia, 2(1), 12-16.

Koutroumanis, D. A., Watson, M. A., \& Dastoor, B. R. (2011). Developing Organizational Culture In Independently Owned Restaurants: Links To Service Quality And Customers Intentions To Return. The Journal of Applied Business Research, 28(1), 15-25.

Kurniawati, E. P., Nugroho, P. I., \& Arifin, C. (2012). Penerapan Akuntansi pada Usaha Mikro Kecil dan Menengah (UMKM). Jurnal Manajemen dan Keuangan, 10(2), 1-10.

Lutfiaazahra, A. (2015). Implementasi Standar Akuntansi Keuangan Entitas tanpa Akuntabilitas Publik (SAK-ETAP) pada UMKM Pengrajin Batik di Kampoeng Batik Laweyan Surakarta. Paper presented at the Seminar Nasional Pendidikan Ekonomi \& Bisnis, Surakarta.

Narsa, I. M., Widodo, A., \& Kurnianto, S. (2012). Mengungkap kesiapan UMKM dalam implementasi standar akuntansi keuangan entitas tanpa akuntabilitas publik (PSAK-ETAP) untuk meningkatkan akses modal perbankan. Majalah Ekonomi, 22(03), 204-214.

Owoyemi, O. O., \& Ekwoaba, J. O. (2014). Organisational Culture: A Tool for Management to Control, Motivate and Enhance Employee's Performance. American Journal of Business and Management, 3(3), 168-177.

Park, K. J., \& Yoo, Y. (2016). Improvement Of Competitiveness In Small And Medium-Sized Enterprises. The Journal of Applied Business Research, 33(1), 173-193.

Petts, J., Herd, A., Gerrard, S., \& Home, C. (1999). The Climate and Culture of Environmental Compliance within SMEs. Business Strategy and the Environment, 8, 14-30.

Priyatno, D. (2009). Akuntansi Sederhana untuk UKM dengan MS Excel. Yogyakarta: Media Kom.

Putri, N. K., Purwati, A. S., \& Suparlinah, I. (2015). The Effect of SAK ETAP Implementation to the Use of Accounting Information at SMEs in Banyumas Region, Central Java, Indonesia. Economica, 11(6), 117-124.

Rabie, C., Cant, M. C., \& Wiid, J. A. (2016). Training And Development In SMEs: South Africa's Key To Survival And Success? The Journal of Applied Business Research, 32(4), 1009-1023. 
Robbins, S. P., \& Coulter, M. (2012). Management (11 ed.). New Jersey: Prentice Hall.

Rudiantoro, R., \& Siregar, S. V. (2012). Kualitas Laporan Keuangana UMKM serta Prospek Implementasi SAK ETAP. Jurnal Akuntansi dan Keuangan Indonesia, 12(1), 1-21.

Saragih, F., \& Surikayanti. (2015). Analisis Penerapan Akuntansi dan Kesesuaiannya dengan SAK ETAP pada UKM Medan Perjuangan. Paper presented at the Seminar Nasional Ekonomi Manajemen dan Akuntansi (SNEMA), Padang.

Sarwono, H. A. (2015). Profil Bisnis Usaha Mikro, Kecil dan Menengah (UMKM). Jakarta: Lembaga Pengembangan Perbangkan Indonesia.

Senarathna, I., Warren, M., Yeoh, W., \& Salzman, S. (2014). The influence of organisation culture on E-commerce adoption. Industrial Management \& Data Systems, 114(7), 1007-1021.

Sudaryanto, Ragimun, \& Wijayanti, R. R. (2013). Strategi pemberdayaan UMKM menghadapi pasar bebas ASEAN Retrieved January 19, 2017, from http://www.kemenkeu.go.id

Suliyanto, Suroso, A., \& Jati, D. P. (2013). Potential and Problems of Small Medium Entreprise (SMEs) Coconut Sugar: Case study in Banyumas Regency, Central Java. International Journal of Business and Management, 8(3), 18-26.

Supriyati, \& Wulanditya, P. (2012). The SME perception towards the Accounting Standard without Public Accountability (SAKETAP) and self Assessment System for Increasing Voluntary Tax Compliance. IAMURE International Journal of Business and Management, 4, 1-19.

Susanto, B. S., \& Yuliani, N. L. (2015). Prospek Implementasi SAK-ETAP Berbasis Kualitas Laporan Keuangan UMKM. Jurnal Ekonomi dan Bisnis Optimum, 5(1), 1-17.

Tambunan, T. T. H. (2011). Development of small and medium enterprises in a developing country. Journal of Enterprising Community, 5(1), 68-82.

Widhiarso, W. (2012). Pemodelan Persamaan Struktural (SEM) pada Data yang Tidak Normal Retrieved January 12, 2017, from http://widhiarso.staff.ugm.ac.id

Widyastutik, W., Mulyati, H., \& Putri, E. I. K. (2010). Analisis Faktor-faktor yang Mempengaruhi Pengembangan Klaster UMKM Alas Kaki di Kota Bogor yang Berdaya Saing. Journal of Management \& Agribusiness, 7(1), 16-26.

Yanto, H., Handayani, B. D., Solikhah, B., \& Mula, J. M. (2016). The Behavior of Indonesian SMEs in Accepting Financial Accounting Standard Without Public Accountability. International Journal of Business and Management Science, 6(1), 43-62.

Yeşil, S., \& Kaya, A. (2012). The role of Organisational Culture on Innovation Capability: An Empirical Study. International Journal of Information Technology and Business Management 6(1), 11-25.

Zahro, F., \& Wahyundaru, S. D. (2015). Determinan Kebutuhan SAK-ETAP bagi UKM (Studi Empiris Pada UKM Makanan di Kota Semarang). Paper presented at the 2nd Conference in Business, Accounting, and Management, Semarang.

Zakaria, N., Zainal, S. R. M., \& Nasurdin, A. M. (2012). Investigating the role of human resource management practices on the performance of SME: a conceptual framework. Journal of Global Management, 3(1), 74-92.

Zen, S. D., \& Herman, M. (2012). Pengaruh Harga Saham Umur Perusahaan dan Rasio Profitabilitas Perusahaan terhadap Tindakan Perataan Laba yang Dilakukan oleh Perusahaan Perbankan yang Terdaftar di Bursa Efek Jakarta. Jurnal Akuntansi \& Manajemen, 2(2), 57-71. 